\title{
The Effect of Job Insecurity on Innovative Work Behavior through Organizational Commitment in UFO Elektronika Employees
}

Dian Fauziawati ${ }^{*}$,

Dewie Tri Wijayati Wardoyo ${ }^{2}$,

12 Department of Management, Faculty Economics and Business, Universitas Negeri Surabaya

\begin{tabular}{|c|c|}
\hline ARTICLE INFO & ABSTRACT \\
\hline $\begin{array}{l}\text { ISSN: 2723-1097 } \\
\text { Keywords: } \\
\text { Innovative Work } \\
\text { Behavior; Job } \\
\text { Insecurity; } \\
\text { Organizational } \\
\text { Commitment }\end{array}$ & $\begin{array}{l}\text { UFO Elektronika is a brand used by PT Damai Sejahtera Abadi, company engaged } \\
\text { in furniture and electronic retail, which was founded in 2003. This study aims to } \\
\text { determine and explain the effect of job insecurity on innovative work behavior with } \\
\text { organizational commitment as an intervening variable on UFO Elektronika } \\
\text { employees. This is a quantitative study with a sample of } 41 \text { employees using the } \\
\text { saturated sampling technique. The statistical analysis used SEM-PLS with } \\
\text { SmartPLS } 3 \text { software. The results explained that job insecurity has a negative } \\
\text { significant effect on organizational commitment, job insecurity has a negative } \\
\text { significant effect on innovative work behavior, organizational commitment has a } \\
\text { positive significant effect on innovative work behavior, and organizational } \\
\text { commitment are able to mediate the relationship between job insecurity and } \\
\text { innovative work behavior. The implementation of research that can be applied to } \\
\text { companies is the creation of a suggestion box that can be filled in by employees to } \\
\text { report conditions in the workplace to minimize work insecurity caused by several } \\
\text { factors and communicate problem solving together, compile an organizational } \\
\text { culture to strengthen the bonds of value, company values for employees, and } \\
\text { rewarding employees who are active in proposing innovative ideas for the success } \\
\text { of the company. }\end{array}$ \\
\hline
\end{tabular}

\section{Introduction}

In the current industrial era where the transformation of the global economy is becoming more rapid, companies must face a constantly changing competitive environment (Tang et al., 2019). The phenomenon that occurs is a change in government regulations that require several industries to work from home because the Covid-19 pandemic has made the public's need for technology and furniture increase. UFO Elektronika is an electronics and furniture retail company that is constantly innovating to develop its business. The president director of UFO Elektronika explained that there was an increase in sales of electronic goods and household furniture by $10 \%$ due to the shift from the face-to-face system to work from home and school from home. This shows that UFO Electronics has an opportunity to develop its business.

Journal of Business and Management Review Vol. 2 No. 62021 Page 401-416

DOI: $10.47153 /$ jbmr26.1702021

*Corresponding Author

Email address: dfauziawati@gmail.com 
To deal with today's business developments, employee creativity and innovation are recognized as the key to facing competitive competition and supporting the company's success (Nguyen et al., 2019). Innovation and creativity in the workplace are needed as strategic priorities to solve problems related to adapting products and work environments to existing changes (Ansari et al., 2018). Companies are able to respond to environmental challenges faster and better if they have an innovative spirit (Wijayati et al., 2018). Employees play a major role in the world of work because they are the ones who develop innovative ideas and the asset to achieve goals (Widyaningsih, 2020). The role of employees in developing creativity and innovation can be seen through innovative work behavior. Innovative employees are employees who are able to introduce, create, and implement new thinking within the company so that they become important assets for the company (Susomrith, 2018).

The factor that can affect innovative work behaviour is job insecurity. Job insecurity occur because of unemployment, environmental change, workplace conditions, and restructurisation that can affect to employees income, productivity, and mental health (Anggrianto et al., 2021) . Employees feelings of job insecurity can affect innovative work behavior because the innovation process requires long-term incentives and employees tend to choose not to innovate because innovative work behavior can lead to worsening relationships with colleagues and supervisors so that employee innovations run the risk of conflict with other employees who want to reject or can't accept change. Probst et al. (2020), Hootegem et al. (2017), Choi et al. (2018), Ardy (2018), and Ludy (2019) found that the effect of job insecurity on innovative work behavior was negative and significant. However, in contrast to Bani-Melhem et al. (2018), Kurniawan (2019), and Niesen et al. (2018) which states that job insecurity cannot affect innovative work behavior.

In understanding other factors that can affect innovative work behavior and job insecurity, organizational commitment is one aspect that can increase innovative behavior (Handayani, 2020). Organizational commitment is defined as the psychological attachment, and willingness of individual members, to make efforts for their organization to maintain membership in the company (Kim, 2020). Committed employees will show their voluntary behavior and have a strong desire to serve their organization to pay for the effort in providing awareness for organizational goals beyond passive loyalty (Ismail, 2019). Organizational commitment helps employees identify their goals with the company and motivates employees to stay in it (Saud, $\underline{2020)}$.

Job insecurity has an effect that can disrupt employee motivation and morale so that effectiveness and efficiency at work are disrupted (Abidin, 2019). The definition shows that job insecurity is related to subjective feelings and perceptions of job insecurity can have a negative impact on attitudes towards work, so that it can be considered a chronic stressor in the workplace. Feelings about insecurity in the world of work can threaten commitment in the organization (Ezra, 2019). Job insecurity that arises either through oneself or the surrounding environment can create discomfort in 
carrying out work so that it can result in low levels of organizational commitment. Kerse et al. (2018), Choi et al. (2018), Lee (2017), Ezra (2019), Gunawan (2020), Udayani (2018), and Indrayani (2020) state that the effect of job insecurity on organizational commitment is negative and significant. However, in contrast to Nurleni et al. (2020) stated that job insecurity has a positive and insignificant relationship to organizational commitment. To achieve work targets, companies must have resources that support and fully contribute to the achievement of these goals. One of the drivers to achieve company goals is to have employees who are good citizens, can work in teams, and are active in innovating which can arise because employees have a high sense of commitment to the company (Elshifa et al., 2019).

Tang et al. (2019) stated that organizational commitment refers to the willingness to devote oneself and be loyal to an organization. Hence organizational commitment is an internalized normative force that promotes the willingness of organizational members to the goals and interests of the organization. Highly committed employees are motivated to engage in increasing creativity and innovation because this creativity is often the main key in salary increases and promotions (Serna et al., 2018). Collaboration among employees facilitates the transfer and accumulation of knowledge, the flow of ideas and experiments that can be used as material for initiating innovation (Wijayati et al., 2018). A series of innovation processes requires several employees who are committed to exchanging knowledge and creating a favorable atmosphere of innovation. Research conducted by Elshifa et al. (2019), Ismail (2019), Tang et al. (2019), Dahri (2018), Bak (2020), and Ali et al. (2020) showed the results that the effect of organizational commitment on innovative work behavior was significantly positive. However, Serna et al. (2018) stated that there was no effect on the relationship between organizational commitment and innovative work behavior.

Based on the issues above, the purpose of this study is to determine and analyze the effect of job insecurity on innovative work behavior through organizational commitment to UFO Elektronika employees.

\section{Literature Review}

Innovative work behavior is behavior in generating innovations related to the creation, promotion, and realization of ideas to improve and develop the work environment and deal with problems effectively (Yousaf et al., 2021). In an organization, an innovation arises through the innovative work behavior of employees because they always respond, hold, and adapt new ideas (Haider, 2017). Employee innovative work behavior can be distinguished from employee creativity for two reasons. First, creativity focuses on the generation of the idea phase, while innovative work behavior is related to the innovation process. Second, creativity traditionally refers to the creation of something completely new (Siregar, 2017). Innovative behavior is supported by employee creativity. The importance of creativity as a driver of innovation and the success of an organization forces the organization to create a work environment that supports creative thinking (Rochani, 2020). 
In relation to innovation, emotional stress from job insecurity can affect creativity and innovative behavior. Job insecurity can be defined as the subjectively perceived probability of unintentional job loss associated with various stress reactions, such as feelings of anxiety, depression, somatization and psychiatric symptoms (Niesen et al., 2018). As a result, emotional stress can affect creativity and innovative behavior. A high level of job insecurity can result in fewer responses to creative ideas in solving problems in the organization (Choi et al., 2018). Job insecurity has four important elements in it, namely the desired work continuity, threats, risky work aspects, and powerlessness. This element will appear when employees begin to feel insecure about themselves related to things related to their work (Ridho, 2018). In addition to focusing on the threat of job loss, job insecurity also includes problems of career opportunities and changing working conditions that are getting worse (Ardy, 2018).

Organizational commitment has been found to contribute significantly to innovative behavior in a positive way. Ezra (2019) mentions organizational commitment as a desire to always try to be part of the company so that employees have confidence and shared values to achieve company goals. Organizational commitment impacts business performance in many forms as an aid to predicting employee behavior. Committed employees make greater efforts to achieve company targets and have more positive relationships within the organization (Serna et al., 2018). Committed employees will show their voluntary behavior and have a strong desire to serve their organization to pay for the effort in providing awareness for organizational goals beyond passive loyalty (Ismail, 2019).

Organizational commitment has a positive effect on innovative behavior because committed employees have better performance and always strive for improvement, and are more willing to engage in innovative behavior (Choi et al., 2018). To overcome problems related to job insecurity, the role of organizational commitment is needed to manage job insecurity and as a basis for developing innovative behavior. The role of organizational commitment that can mediate the relationship between job insecurity and innovative work behavior is reinforced by research from Siregar et al. (2021) and Choi et al. (2018) which state that the higher the level of organizational commitment, it can reduce the level of job insecurity so that it can increase employee innovative behavior. So organizational commitment can mediate the relationship between job insecurity and innovative behavior. So that organizational commitment plays an important role where with a high level of organizational commitment, employees can improve their innovative work behavior.

\section{Method}

This type of research is quantitative with the variables used are job insecurity $(X)$, organizational commitment $(\mathrm{Z})$, and innovative work behavior (Y). The research location is at UFO Electronics on Jalan Kertajaya No. 149 Surabaya. The research population was 50 employees represented by each division. The number of samples is 41 employees using the saturated sample technique. Saturated sampling technique is 
a technique in taking research samples by using the entire population as the research sample. This study uses the saturated sample technique because the number of employees is not too many and the use of the saturated sample technique is sufficient for all divisions in the company. Retrieval of research data using literature studies (articles and news), observation, interviews, and distributing questionnaires. The questionnaire measurement scale is a Likert scale with a score of 1-5 with categories Strongly Disagree (STS), Disagree (TS), Neutral (N), Agree (S), and Strongly Disagree (STS). The data analysis technique used SEM-PLS with the help of the Smart-PLS 3 statistical analysis software.

The measurement of the independent variable of job insecurity uses 7 measurement items from Hellgren et al. (1999) using two indicators including quantitative job insecurity and qualitative job insecurity. Quantitative job insecurity refers to concerns about one's potential job loss, whereas qualitative job insecurity reflects a perceived threat to valued aspects of one's position (e.g. decreased working conditions, reduced career opportunities).

The measurement of intervening organizational commitment variable uses 9 measurement items modified from Bangun et al. (2017) using three indicators including affective, normative, and continuance commitment. Affective commitment is an employee's emotional bond with his involvement in the company, normative commitment is an employee's belief about his responsibility to the company, and continuance commitment is a commitment based on consideration of employee benefits in the company so that employees tend to stay because they think about the losses experienced if they leave the company.

The measurement of dependent variable innovative work behavior using 14 measurement items from Kleysen \& Street (2001) using five indicators including opportunity exploration, generativity, formative investigation, championing, and application. (1) Opportunity exploration is an activity to explore something extensively to learn more about it. The first factor of innovative behavior relates to the metaphor of traveling extensively through innovation opportunities to learn or discover more about something. (2) Generativity is an interest in building and guiding the next generation, even though there are people who do not apply this drive to their offspring. (3) Formative investigation is a form of concern by providing an overview and finding out ideas, solutions, and opinions and trying them out through investigation. (4) Championing consists of socio-political behavior involved in the innovation process to realize the potential of ideas, solutions, and innovations. (5) Application is an effort to make innovation a regular part of business as usual. Behavior that reflects the application is implementing ideas, modifying ideas, and implementing changes on a regular basis.

\section{Result and Discussion}

Statistical Test Results 
The results of the validity test aim to test the feasibility of the statement items in the questionnaire. The statement items on the questionnaire are declared valid if the loading factor value is more than 0.70 . Figure 2 shows all indicators showing values $>$ 0.70 so all indicators are declared valid.

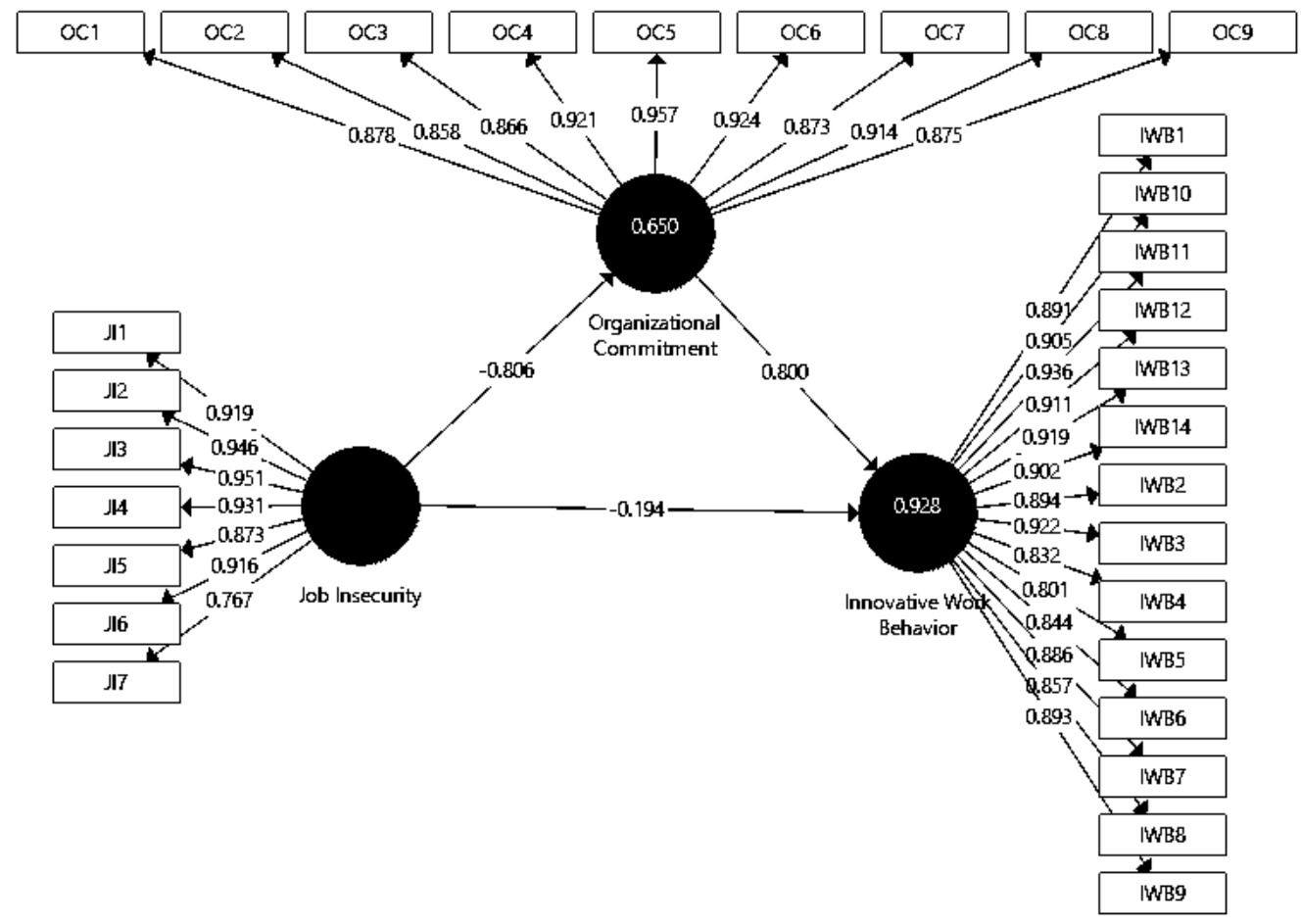

Figure 2. Inner Model

The results of the reliability test aim to measure an indicator on the variables in the questionnaire. A variable can be declared reliable if the answers from respondents to the statement are consistent from time to time. Reliability testing in this study uses the construct reliability test by testing the reliability and consistency of the data. Reliability meets the criteria if the construct reliability value is greater than 0.70

Table 1. Statistical Result

\begin{tabular}{cccc}
\hline Variabel & $\begin{array}{c}\text { Composite } \\
\text { Reliability }\end{array}$ & $\begin{array}{c}\text { Cronbach's } \\
\text { Alpha }\end{array}$ & R-Square \\
\hline $\begin{array}{c}\text { Job Insecurity } \\
\text { Organizatonal } \\
\text { Commitment } \\
\text { Innovative Work } \\
\text { Behavior }\end{array}$ & 0,968 & 0,961 & \\
\hline
\end{tabular}

Source: Output SmartPLS 3 
Table 2 shows the results of data analysis showing the composite reliability value of each variable is more than 0.70 so that the data is reliable. Cronbach's alpha value is more than 0.70 , then all variables have met the minimum standards set. The $r$-square value of the organizational commitment variable is 0.650 . So that exogenous variables can explain the effect on organizational commitment by $65 \%$ and the remaining $35 \%$ is explained by variables in other studies. The r-square value of the innovative work behavior variable is 0.928 so that the exogenous variable can explain its effect on innovative work behavior by $92.8 \%$ and the remaining $7.2 \%$ is explained by variables in other studies.

In addition to R-Square, variable constructs can also be calculated using the QSquare predictive relevance formula. The formula for calculating the Q-Square predictive relevance of research can be seen in formula (1).

$$
\begin{aligned}
& Q^{2}=1-\left(\sqrt{1-R_{1}^{2}}\right) \times\left(\sqrt{1-R_{2}^{2}}\right) \\
& =1-(\sqrt{1}-0,6502) \times(\sqrt{1}-0,9282) \\
& =1-(\sqrt{0,5775}) \times(\sqrt{0,138816}) \\
& =1-(0,76 \times 0,37) \\
& =0,72
\end{aligned}
$$

From these calculations, the results of the q-square predictive relevance of 0.72 are obtained. This shows that the research model has a predictive relevance value that can explain the research by $72 \%$.

\section{Path Coefficients}

The size of the significance of the support for the hypothesis can be detected by using a comparison between the T-statistical values and the T-table. If the T-statistic value is greater than the T-table value, the hypothesis is accepted. The T-table value at the $95 \%$ or 0.05 confidence level is 1.96 . So, if the T-statistic value is greater than 1.96 then the hypothesis is accepted.

Tabel 2. Path Coefficients

\begin{tabular}{ccccc}
\hline $\begin{array}{c}\text { Relationship } \\
\text { between Variabel }\end{array}$ & $\begin{array}{c}\text { Original } \\
\text { Sampel }\end{array}$ & $\begin{array}{c}\text { T- } \\
\text { Statistics }\end{array}$ & P-Value & Result \\
\hline $\mathrm{JI} \rightarrow \mathrm{IWB}$ & $-0,194$ & 2,590 & 0,010 & H1 accepted \\
$\mathrm{JI} \rightarrow$ OC & -806 & 29,023 & 0,000 & H2 accepted \\
$\mathrm{OC} \rightarrow I W B$ & 0,800 & 11,885 & 0,000 & H3 accepted \\
\hline
\end{tabular}

\section{Source: Output SmartPLS 3}

The T-statistic value of the job insecurity variable on innovative work behavior is 2.590> 1.96 so that $\mathrm{H} 1$ is accepted. This shows that the relationship between job 
insecurity and innovative work behavior is significant. While the coefficient estimate value is -0.194 with a negative sign, the lower the level of job insecurity, the higher the level of innovative work behavior.

The T-statistics value of the job insecurity variable on organizational commitment is $29,023>1.96$ so that $\mathrm{H} 2$ is accepted. Then the relationship between the variable job insecurity and organizational commitment is significant. While the coefficient estimate value is -0.806 with a negative sign, the lower the level of job insecurity, the higher the level of organizational commitment.

The T-statistic value of the organizational commitment variable on innovative work behavior is $11.885>1.96$ so that $\mathrm{H} 3$ is accepted, the relationship between organizational commitment and innovative work behavior is significant. While the coefficient estimate value is 0.800 with a positive sign which means the higher the level of organizational commitment, the higher the level of innovative work behavior.

\section{Indirect Effects}

Indirect effect is defined as the indirect effect between the independent variables on the dependent variable because there is an intermediate variable (mediation) that connects the two variables. The size of the significance of the support for the hypothesis can be detected by using a comparison between the T-statistical values with the T-table. If the T-statistic value is greater than the T-table value, the hypothesis is accepted. The T-table value at the $95 \%$ or 0.05 confidence level is 1.96 . So, if the Tstatistic value is greater than 1.96 then the hypothesis is accepted.

The indirect effect of job insecurity on innovative work behavior through organizational commitment is -0.645 with a T-statistics value of $10.229>1.96$, which is significant. Based on the above calculation, $\mathrm{H} 4$ is accepted and organizational commitment is able to mediate the relationship between job insecurity and innovative work behavior.

Tabel 4. Indirect Effects

\begin{tabular}{ccccc}
\hline $\begin{array}{c}\text { Relationship } \\
\text { between Variabel }\end{array}$ & $\begin{array}{c}\text { Original } \\
\text { Sampel }\end{array}$ & $\begin{array}{c}\text { T- } \\
\text { Statistics }\end{array}$ & P-Value & Result \\
\hline $\mathrm{JI} \rightarrow$ OC $\rightarrow \mathrm{IWB}$ & $-0,645$ & 10,229 & 0,000 & $\begin{array}{c}\mathrm{H} 4 \\
\text { accepted }\end{array}$ \\
\hline
\end{tabular}

Source: SmartPLS 3

\section{Effect of Job Insecurity on Innovative Work Behavior}

The test results show that job insecurity has a negative and significant effect on innovative work behavior. The average value of respondents' answers for the variable 
innovative work behavior is in the high category. So that employees have a high level of innovative behavior. UFO Elektronika employees are able to be involved in the innovation process with the aim of realizing the potential of new ideas, providing solutions to problems that occur, and also having innovative thinking to achieve mutual success. However, some employees still have feelings of insecurity at work because they have concerns about their position in the company. The level of education of employees affects the mindset and behavior of employees in the company because there are differences in behavior between employees who have a high school education with a Diploma/Bachelor degree. This can be seen from the habits of employees who have doubts because they often differentiate themselves from other employees. However, this can foster a sense of innovation because employees have critical thinking and dare to express opinions and provide input on problems that occur and solve together in the best way.

In this case, the role of superiors is very influential because they are able to manage problems very well such as receiving every input from employees, solving problems in a good way, and not discriminating against employees based on background. So that UFO Elektronika employees are able to reduce anxiety about unsafe conditions in their work and further increase their enthusiasm to take part in the success of the company through their innovative behaviors. Therefore, UFO Elektronika employees are able to carry out innovation activities and develop their ability to provide new strategies in dealing with the constantly changing work environment in accordance with external changes.

Based on the explanation above, it can be seen that UFO Elektronika employees have a low level of job insecurity because they get good treatment from superiors so that employees have a high level of innovative work behavior that can make employees able to work well together in advancing the company. The results of this test are in line with the research of Probst et al. (2020), Hootegem et al. (2017), Choi et al. (2018), Ardy (2018), and Ludy (2019).

\section{Effect of Job Insecurity on Organizational Commitment}

The test results show that job insecurity has a negative and significant effect on organizational commitment. The results of respondents' answers for the job insecurity variable have an average value in the medium category. Meanwhile, respondents' answers to the organizational commitment variable have an average value in the high category. The job insecurity indicator that has the highest average value is quantitative job insecurity and the organizational commitment indicator that has the highest average value is normative commitment. The average employee explains that career opportunities in the company are still in doubt by the majority of employees which can be caused by differences in education level, ability, expertise, and length of service of employees in the company. On the other hand, employees also have dissatisfaction about salary developments in the company. This is due to differences in the amount 
of employee salaries that are adjusted to the company's ability, performance evaluation, length of service, and their position.

However, the company has been able to control the employee's sense of job insecurity because the company provides policies that can reduce the level of work insecurity that employees have. For example, the educational background of employees is dominated by high school education rather than diploma or bachelor's degree and the age of employees ranging from 16 to 50 years. In this case, the company provides opportunities for employees who can work well in accordance with the job description that is set and meet self-specifications in accordance with company values, so these employees have the opportunity to join and work together.

Judging from the current phenomenon, namely the rapid environmental change and restructuring, this level of job insecurity can motivate employees to improve their performance because employees are afraid of losing their jobs and industry competition is becoming more intense so it is very difficult to get new jobs in the industry. soon. To keep working in the company, employees tend to give their best contribution by completing their duties well. This can be proven by the average length of service for UFO Electronics employees about 10 years.

The organizational commitment indicator that has the highest average value is normative commitment. Employees have a normative commitment which is an employee's belief about his or her responsibility to the company. UFO Elektronika employees contribute well such as arriving on time, completing assignments on time, working hard to meet targets, and being responsible for every obligation that must be done. This normative commitment of employees can be supported by the similarity of company values with individuals, a company environment that inspires employees to always contribute actively, and also support from superiors and colleagues. So that the company is good at providing policies to employees so that it can reduce the level of job insecurity owned by employees and make employees have a high sense of commitment to keep working at the company and participate in supporting the company in achieving success. Thus, UFO Elektronika employees have a low level of job insecurity and a high level of organizational commitment with a negative relationship between these two variables. Thus these results are in line with the research of Kerse et al. (2018), Choi et al. (2018), Lee (2017), Ezra (2019), Gunawan (2020), Udayani (2018), and Indrayani (2020).

\section{The Effect of Organizational Commitment on Innovative Work Behavior}

The test results show that organizational commitment has a positive and significant effect on innovative work behavior. Organizational commitment refers to the willingness of employees to devote themselves and be loyal to the organization. Therefore, organizational commitment is a force that drives the willingness of members to conform to the goals and interests of the company. Employees will agree with organizational goals and values if they have a strong sense of commitment, and 
are more willing to express extra role behaviors (Tang et al., 2019). This happens because innovative work behavior is an expression of their extra role behavior which is based on a sense of commitment to the company so that employees are willing to carry out innovative activities to create company goals.

Based on the phenomenon that occurred at UFO Electronics, the level of employee commitment is quite high. The average value of the results of employee answers on the organizational commitment questionnaire is included in the high category. UFO Elektronika employees always carry out each task properly and in accordance with their respective job descriptions. The level of discipline is very high because employees always come on time and are never late. This can be seen from the fingerprint tool data that has been prepared.

Related to its influence on innovative work behavior, the company's current income has increased due to the increasing need for electronic goods to conduct school activities and work online. The leader of UFO Electronics, Mr. Poedji has an innovative idea to continuously increase revenue during the pandemic, namely by holding an electronic equipment exhibition which is held at Tunjungan Plaza III. This thought emerged from the analysis of consumer needs during a pandemic who needed electronic goods to carry out daily activities due to the many restrictions in the outside environment. For example, the closing of cinemas that make consumers buy televisions with larger sizes, the hot air temperature because they are inside the house so that consumers buy air conditioners, and also the increasing number of people making a living from home so they buy cooking utensils and home appliances to stay productive. make money during a pandemic.

To increase income during a pandemic, employees provide new breakthroughs such as switching the sales system from offline to online so that UFO Elektronika employees often do live sales or online sales via Instagram. To further increase buyer interest, the management will provide attractive offers to buyers such as discounted prices for the purchase of certain products or by buying electronic goods beyond the specified minimum spending. In addition, the existence of a giveaway or distribution of prizes is also an innovative idea to expand the promotion and reach of the company because giveaway participants are required to confirm the electronic goods they want on social media that they have as much as possible by including the specifications of the goods and the advantages of the goods that allow adding to the expansion of the UFO Electronics target market and adding new consumers. This caused UFO Electronics to successfully increase its revenue by $10 \%$ and exceed its sales target. Therefore, the commitment of UFO Elektronika employees is very high so that they have high innovative thinking to participate in increasing the company's revenue (Marques et al., 2013). These results are in line with the research of Elshifa et al. (2019), Ismail (2019), Tang et al. (2019), Dahri (2018), Bak (2020), and Ali et al. (2020).

The Effect of Job Insecurity on Innovative Work Behavior through Organizational Commitment 
The test results show that organizational commitment can mediate the relationship between job insecurity and innovative work behavior. The results of employee interviews and questionnaires state that employees have a high level of organizational commitment because the organizational commitment variable has a high category average value. In this case, employees fully support the importance of employee innovation to support the company's success because this innovation is needed to make the company continue to grow against competition. Judging from the latest innovations from the top management of UFO Elektronika who are planning to open new branches in several cities to expand their market, UFO Elektronika employees fully support the opening of the branch by participating in the planning process and doing everything to support the establishment of the new branch. Top management chose this innovation as market expansion because they thought that the creation of stores in several areas would make it easier for people to fulfill their electronic needs by buying these goods which were located close to their homes.

Another thing that can explain the role of organizational commitment as mediation is that UFO Elektronika employees are willing to follow the rules set by superiors such as being a senior employee at the opening of a new branch to train prospective employees according to the agreed system and provide innovative ideas for the company's success because of the management New branches require high innovation and creativity to survive in the industry against more experienced competitors. Employees who have work insecurity can be mediated by a sense of commitment to the organization by participating in advancing the company, including in supporting the opening of new branches and being a part of it. This can reduce the level of employee job insecurity because by becoming a senior employee in a new branch, the employee will have job security, career development, salary development, and also a more profitable position.

The explanation above shows that organizational commitment can mediate the relationship between job insecurity and innovative work behavior where UFO Electronics employees have a high level of organizational commitment to the company so that this commitment can make employees care about business continuity in the company and try to be part of all activities that aims to achieve company goals. The importance of innovation today can make employees enthusiastic in moving forward so that the insecurity of working that employees have can be managed properly because employees try to maintain their employment status in the company so they are not expelled from the company by using the organizational commitment variable as an intermediary. The results of this test are in line with the research of Siregar et al. (2021), Wijayati et al. (2018), Choi et al. (2018), and Rochani (2020).

\section{Conclusion}

Job insecurity has a negative and significant effect on organizational commitment. This shows the level of organizational commitment owned by UFO Elektronika employees can reduce the level of job insecurity owned by employees. 
This is supported by the support of superiors, the motivation of co-workers, and also very good policies at UFO Electronika. Then job insecurity has a negative and significant effect on innovative work behavior. This shows that the level of innovative work behavior possessed by employees can reduce the level of job insecurity because having innovative behavior will make employees get good career opportunities. Meanwhile, organizational commitment has a positive and significant effect on innovative work behavior. This shows that UFO Elektronika employees have a high level of organizational commitment so that employees have high innovative attitudes and behaviors that can be distributed or applied in the workplace to achieve maximum results. And organizational commitment can mediate the relationship between job insecurity and innovative work behavior. The level of job insecurity owned by employees can be minimized by a sense of commitment to the company because this sense of commitment can make employees more active to contribute to achieving company success by conveying creative ideas or by developing innovative behavior.

Future research is expected to be able to find other problem topics that are still related to innovative work behavior because the existence of this scope is still quite rare. Examples of variables that can be used are work engagement, job autonomy, and work life balance.

\section{Acknowledgment}

I would like to express my gratitude to all parties involved in this research, especially UFO Electronics employees, management lecturers at the Faculty of Economics and Business at the State University of Surabaya, both parents and the entire family who have always provided enthusiasm and motivation in completing this scientific article, and all friends who have always supported and supported me. there to help me in the research process.

\section{References}

Abidin, M. J. (2019). Pengaruh Job Insecurity, Kepuasan, dan Motivasi Kerja terhadap Turnover Intention Karyawan Kontrak. Jurnal Ilmu Dan Riset Manajemen, 8, 9.

Ali, M., Raza, B., Ali, W., \& Imtiaz, N. (2020). Linking Managerial Coaching with Employees ' Innovative Work Behaviors through Affective Supervisory Commitment: Evidence from Pakistan. International Review of Management and Marketing, 10(4), 11-16. https://doi.org/https://doi.org/10.32479/irmm.9715

Anggrianto, D., Djatmika, E. T., \& Rahayu, W. P. (2021). Entrepreneurial Intention : The Moderating Role of Improvisation on Student Faculty of Economics, Universitas Negeri Malang. Journal of Business and Management Review, 2(4), 318335. https://doi.org/10.47153/jbmr24.1342021

Ansari, N. Y., Siddiqui, S. H., \& Farrukh, M. (2018). The Effect of High Performance Work Practices on Employee Innovative Behavior: The Mediating Role of Job Embeddedness. International Journal of Contemporary Econmics and Administrative Sciences, 8(2), 64-88.

Ardy, Ludi Prasetyo. (2018). Pengaruh Job Insecurity terhadap Perilaku Kerja Inovatif 
melalui Mediasi Work Engagement. Jurnal Psikologi, 27(2), 30-49. http://jurnal.untag-sby.ac.id/index.php/fenomena\%0AVolume

Ardy, Ludy Prasetyo, \& Fajrianthi. (2019). Job Autonomy sebagai Moderator pada Pengaruh Job Insecurity terhadap Perilaku Kerja Inovatif. Jurnal Psikologi Teori Dan Terapan, 9(2), 101-111.

Bak, H. (2020). Supervisor Feedback and Innovative Work Behavior: The Mediating Roles of Trust in Supervisor and Affective Commitment. Frontiers in Psychology, 11. https:// doi.org/10.3389/fpsyg.2020.559160

Bangun, O. V., Supartha, I. W. G., \& Subudi, M. (2017). Pengaruh Person-Job Fit dan Person-Organization Fit terhadap Komitmen Organisasional dan Organizational Citizenship Behavior (OCB). E-Jurnal Ekonomi Dan Bisnis Universitas Udayana 6.5 (2017): 2071-2102, 5, 2071-2102. https:/ /ojs.unud.ac.id/index.php/EEB/article/download/29794/18688/

Bani-Melhem, S., Zeffane, R., \& Albaity, M. (2018). Determinants of Employees' Innovative Behavior. International Journal of Contemporary Hospitality Management, 30(3), 1601-1620. https:/ / doi.org/10.1108/IJCHM-02-2017-0079

Choi, S. B., Cundiff, N., Kim, K., \& Akhatib, S. N. (2018). The Effect of Work-Family Conflict and Job Insecurity on Innovative Behaviour of Korean Workers: The Mediating Role of Organizational Commitment dan Job Satisfaction. International Journal Od Innovation Management, 22(1), 1-29. https://doi.org/10.1142/S1363919618500032

Dahri, N. W. (2018). Budaya Organisasional, Kepuasan Kerja, dan Komitmen Organisasional dalam Meningkatkan Perilaku Inovatif. Jurnal Bisnis Teori Dan Implementasi, 9(2), 191-199. http://journal.umy.ac.id/index.php/bti

Elshifa, A., Anjarini, A. D., \& Kharis, A. J. (2019). Pengaruh Quality of Work Life dan Penggunaan Teknologi Informasi terhadap Perilaku Kerja Inovatif Dosen yang dimediasi Komitmen Organisasi. Economicus, 13(2), 189-200.

Ezra, R. F., \& Fitria, Y. (2019). Pengaruh Ketidakamanan Kerja terhadap Intensi Keluar dengan Komitmen Organisasional Sebagai Variabel Mediasi Pada Perawat Kontrakrumah Sakit Umum Citra BMC Padang. Jurnal Kajian Manajemen Dan Wirausaha, 01(37), 183-191.

Gunawan, I. K. A. P., \& Ardana, I. K. (2020). Pengaruh Job Insecurity, Budaya Organisasi, dan Lingkungan Kerja terhadap Komitmen Organisasional. E-Jurnal Manajemen Unud, 9(5), 1858-1878.

Haider, M. H. (2017). Internal Marketing and Employee' s Innovative Work Behavior : The Mediating Role of Job Embeddedness. Bulletin of Education and Research, 39(1), 291-313.

Handayani, E. Y., \& Rahmah, A. (2020). Hubungan antara Komitmen Organisasi dengan Perilaku Inovatif pada Mahasiswa Universitas Negeri Surabaya. Prosiding Seminar Nasional 2020, 228-234.

Hellgren, J., Sverke, M., \& Isaksson, K. (1999). A Two-dimensional Approach to Job Insecurity: Consequences for Employee Attitudes and Well-being. European Journal of Work and Organizational Psychology, 8(2), 179-195.

Hootegem, V., Hiesen, A., \& Witte, D. (2017). Does job insecurity hinder innovative 
work behaviour? A threat rigidity perspective. Research Group for Work, Organizational and Personnel Psychology.

Indrayani, N., \& Suwandana, I. G. M. (2020). Peran Moderasi Status Kepegawaian pada Hubungan Job Insecurity dengan Komitmen Organisasional. E-Jurnal Manajemen, $9(3)$,

1210-1229. https:/ / doi.org/https:/ / doi.org/10.24843/EJMUNUD.2020.v09.i03.p20

Ismail, A. (2019). The Impact of Transformational Leadership and Commitment on Teachers 'Innovative Behaviour. Advances in Social Science, Education and Hunaities Research (ASSEHR), 304(4), 426-430.

Kerse, G., Kocak, D., \& Ozdemir, S. (2018). Does The Perception of Job Insecurity Bring Emotional Exhaustion? The Relationship between Job Insecurity, Affective Commitment and Emotional Exhaustion. Business and Economics Research Journal, 9(3), 651-663. https:// doi.org/10.20409/berj.2018.129

Kim, M., \& Kim, B. (2020). The Performance Implications of Job Insecurity: The Sequential Mediating E ff ect of Job Stress and Organizational Commitment, and the Bu ff ering Role of Ethical Leadership. 5-19.

Kleysen, R. F., \& Street, C. T. (2001). Toward a multi-dimensional measure of individual innovative behavior. Journal of Intellectual Capital, 2(3), 284-296. https:/ / doi.org/10.1108/EUM0000000005660

Kurniawan, R. A. (2019). Effect of Mediation Work Engagement to Leader Member Exchange and Job Insecurity on Innovative Work Behavior. Management Analysis Journal, 8(4).

Lee, S. H., \& Jeong, D. Y. (2017). Job Insecurity and Turnover Intention: Organizatonal Commitment as Mediator. Social Behavior and Personality, 45(4), 529-536. https://doi.org/https://doi.org/10.2224/sbp.5865

Nguyen, V. T., Siengthai, S., Swierczek, F., \& Bamel, U. K. (2019). The effects of organizational culture and commitment on employee innovation : evidence from Vietnam ' s IT industry. Journal of Asia Business Studies, 13(4), 719-742. https://doi.org/10.1108/JABS-09-2018-0253

Niesen, W., Hootegem, A. Van, Elst, T. Vander, Battistelli, A., \& Witte, H. De. (2018). Job Insecurity and Innovative Work Behaviour: A Psychological Contract $\begin{array}{llll}\text { Perspective. } \quad \text { Psychologica 174-189. } & \text { Belgica, }\end{array}$ https:/ / doi.org/http:/ / doi.org/10.5334/pb.381

Nurleni, S., Sunarya, E., \& Mulia, F. (2020). Peran Job Insecurity dan Job Satisfaction terhadap Komitmen Organisasi. Journal of Management and Bussines (JOMB), 2(2), 226-235. https:/ / doi.org/https:/ / doi.org/10.31539/jomb.v2i2.695

Probst, Chizh, A., Hu, S., Jiang, L., \& Austin, C. (2020). Explaining The Relationship Between Job Insecurity And Creativity A Test Of Cognitive And Affective Mediators. Career Development International, 25(3), 247-270. https:/ / doi.org/10.1108/CDI-04-2018-0118

Ridho, S., \& Syamsuri, A. R. (2018). Analisis Pengaruh Job Insecurity dengan Kepuasan Kerja dan Komitmen Organisasi sebagai Variabel Intervening terhadap Intensi Turnover. Jurnal Ilmiah AMIK Labuhan Batu, 6(1).

Rochani, A. G. S. (2020). Empowering Leadership, Kreativitas Karyawan, dan Creative 
Self Efficacy (Studi pada Bank Jatim Kantor Cabang Trenggalek). Jurnal Ilmu Manajemen (JIM), 8(1), 1-8.

Saud, T. R. (2020). The Effect of Job Characteristics on Organizational Commitment: The Role of Growth Need Strength in Nepali IT Companies. Journal of Business and Management Research, 3(1), https:/ / doi.org/https:/ / doi.org/10.3126/jbmr.v3i1.31973

39-56.

Serna, M. del C. M., Martinez, J. E. V., \& Domenech, V. E. (2018). The Influence of Organizational Commitment and Learning Orientation on Innovation in SMEs.

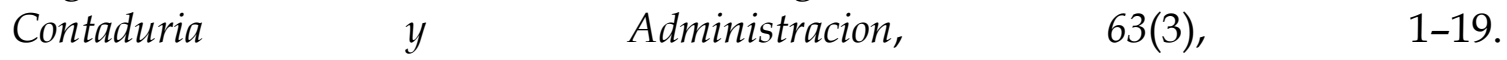
https:/ / doi.org/http://dx.doi.org/10.22201/fca.24488410e.2018.1411

Siregar, S. (2017). Statistik Parametrik untuk Penelitian Kuantitatif: dilengkapi dengan perhitungan manual dan aplikasi SPSS versi 17 (Edisi 1). Bumi Angkasa.

Siregar, Z. M. E., Sujana, F. R., Pranowo, A. S., \& Supriadi, Y. N. (2021). Job Autonomy and Innovative Work Behavior of Marketing Employees in the Automotive Industry in Indonesia : The Mediating Role of Organizational Job Autonomy and Innovative Work Behavior of Marketing Employees in the Automotive Industry in Indonesia: The. QUALITY Access to Success, 22(180), 97-102.

Susomrith, P., \& Amankwaa, A. (2018). Relationship between job embeddedness and innovative work behaviour. https:/ / doi.org/10.1108/MD-11-2018-1232

Tang, Y., Shao, Y., Chen, Y., \& Chen, Y. (2019). Assessing the Mediation Mechanism of Job Satisfaction and Organizational Commitment on Innovative Behavior: The Perspective of Psychological Capital. Frontiers in Psychology, 10, 1-12. https:/ / doi.org/10.3389/fpsyg.2019.02699

Udayani, N. L. P. K., \& Sunariani, N. N. (2018). Budaya Organisasi, Pengembangan Karir, Job Insecurity terhadap Organisational Citizenship Hegaviour dengan Komitmen Organisasional sebagai Variabel Intervening. Jurnal Manajemen Dan Bisnis, 15(2), 151-174.

Widyaningsih, M., \& Arfiansyah, M. A. (2020). The Effect of Leadership Style and Motivation on The Performance of Academic Staff. Journal of Business and Management Review, 1(3), 145-154. https:/ / doi.org/10.47153/jbmr13.292020

Wijayati, D., Fazlurrahman, H., \& Hadi, H. (2018). The Mediating of Change Organization in the Effect of Strategic Leadership Style and Innovation. International Journal of Academic Research in Business and Social Sciences, 8(4), 24-43. https://doi.org/10.6007/IJARBSS/v8-i4/3995

Yousaf, Z., Majid, A., \& Yasir, M. (2021). Is polychronicity a panacea for innovative work behavior among nursing staff ? Job embeddedness and moderating role of decentralization. European Journal of Innovation, 24(1), 173-189. https:/ / doi.org/10.1108/EJIM-06-2019-0172 